\title{
The relationship between periodontite and diabetes mellitus type ii facing the new classification of periodontal diseases: literature review
}

\author{
A relação entre periodontite e diabetes mellitus \\ tipo 2 frente a nova classificação das doenças \\ periodontais: revisão de literatura
}

Lívia Maria Lopes de OLIVEIRA ${ }^{1}$ iD https://orcid.org/0000-0002-7579-9254
Lívia Mirelle BARBOSA² iD https://orcid.org/0000-0002-8992-2890

\begin{abstract}
Periodontal disease and type 2 diabetes mellitus are considered chronic diseases that at their core have a deep relationship with inflammation. It is assumed that there is a bidirectional relationship between periodontal disease and type 2 diabetes mellitus. It is estimated that approximately $10 \%$ of the world's population is affected by periodontal disease, in its most severe form, almost the same percentage estimated for people with diabetes, which is considered a 21st century emergency. The World Workshop for the Classification of Periodontal and Peri-implant Diseases and Conditions took place from September 9-11, 2017. The aim of this study is to analyze the results of this workshop with regard to the relationship between periodontal diseases/conditions and diabetes mellitus, in addition to conducting an integrative review on the topic. A literature review was conducted, using the Medline electronic databases via Pubmed, Scientific Electronic Library Online, Scientific and Technical Literature of Latin America and the Caribbean and Virtual Health Library. A new classification of periodontal disease included tools for individual assessment of the patient and recognizing risk factors that might negatively interfere in response to treatment. The occurrence of metabolic lack of control in periodontal patients with type 2 diabetes mellitus is now considered a factor of great importance for the assessment of individual susceptibility to the progression of periodontitis. Diabetes is believed to promote a hyper inflammatory response to bacterial challenge by modifying the tissue response of periodontal tissues.
\end{abstract}

Indexing terms: Classification. Diabetes mellitus. Diabetes mellitus, type 2. Periodontal diseases.

\section{RESUMO}

A doença periodontal e o diabetes mellitus tipo 2 são consideradas doenças crônicas que tem em seu cerne um profundo relacionamento com mecanismos inflamatórios, pressupõe-se que haja uma relação bidirecional entre doença periodontal e diabetes mellitus tipo 2. Estima-se que aproximadamente $10 \%$ da população do mundo seja afetada pela doença periodontal, na sua forma mais severa, quase

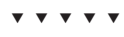

1 Universidade Federal de Pernambuco, Pós-Graduação em Odontologia, Departamento de Prótese e Cirurgia Buco-Facial. Av. Prof. Moraes Rego, 1235, 50670-901, Cidade Universitária, Recife, PE, Brasil. Correspondência para / Correspondence to: LML OLIVEIRA. E-mail: <livialopesperiodontia@gmail.com>.

2 Universidade de Pernambuco, Faculdade de Odontologia. Recife, PE, Brasil.

$\boldsymbol{\nabla} \boldsymbol{\nabla} \boldsymbol{\nabla}$

How to cite this article

Oliveira LML, Barbosa LM. Periodontitis and type 2 diabetes: critical review. RGO, Rev Gaúch Odontol. 2020;68: e20200059. http://dx.doi. org/10.1590/1981-863720200005920190060 
o mesmo percentual estimado para portadores de diabetes, que é considerada uma emergência do século XXI. Entre 9 e 11 de setembro de 2017, ocorreu o World Workshop para a Classificação das Doenças e Condições Periodontais e Peri-implantares. O objetivo deste estudo é analisar o que está colocado por esta classificação sobre a relação entre doenças/condições periodontais e diabetes mellitus, além de fazer uma revisão integrativa a respeito do tema. Foi realizada uma revisão de literatura, a partir das bases de dados eletrônicas Medline via Pubmed, Scientific Electronic Library Online, Literatura Científica e Técnica da América Latina e Caribe, Biblioteca Virtual em Saúde. A nova classificação das doenças periodontais incluiu ferramentas para uma avaliação individual do paciente, reconhecendo fatores de risco que possam interferir negativamente na resposta ao tratamento. A ocorrência de descontrole metabólico em pacientes periodontais com diabetes mellitus tipo 2, passa a ser considerada, então, um fator de grande importância para a avaliação da susceptibilidade individual para a progressão da periodontite. Acredita-se que o diabetes promova uma resposta hiperinflamatória ao desafio bacteriano, modificando a resposta tecidual dos tecidos periodontais.

Termos de indexação: Classificação. Diabetes mellitus. Diabetes mellitus tipo 2. Doenças periodontais.

\section{INTRODUCTION}

Type 2 diabetes mellitus (DM2) is a clinical syndrome with variable phenotypic expression, with no specific etiology. It is considered a disease of polygenic nature mediated by the environment and characterized by bi-hormonal dysfunction of the pancreas [1] and consequent deregulation of homeostasis mechanisms of blood glucose levels [2]. Periodontal disease (PD) is a chronic condition, associated with dysbiotic biofilm and characterized by progressive destruction of dental insertion apparati [3].

PD and DM2 are considered chronic diseases related to habits, lifestyle, socioeconomic factors and which have, at their core, a deep relationship with inflammatory mechanisms [4]. It is estimated that approximately $10 \%$ of the world's population is affected by PD, in its most severe form [5], almost the same percentage estimated for people with diabetes, which is considered to be a 21st century emergency. In Brazil, it is believed that diabetes represents $5 \%$ of total diagnosed chronic diseases $[6,7]$.

It is assumed that there is a bi-directional relationship between DP and DM2 $[4,8]$. Longitudinal studies $[9,10]$ positively associated DM2 with increased risk in developing periodontitis, accelerating its evolution. This association can be explained by the release of hormonal and inflammatory signs related to the pathogenesis of diabetes [1] that can also contribute to tissue destruction, a characteristic of periodontitis.

$\mathrm{PD}$, on the other hand, may be associated with increased risk in developing diabetes complications [4]. There is evidence that periodontal therapy can result in improved glycemic control [11] and that PD can function as a modifying factor for diabetes [4]. The establishment of a possible causal relationship between periodontal condition and DM2, however, remains uncertain [12].

Between September 9 and 11, 2017, the World Workshop for the Classification of Periodontal and Periimplant Diseases and Conditions took place. A committee, organized by the American Academy of Periodontics and the European Federation of Periodontics, updated the 1999 Classification and developed a similar scheme for peri-implant diseases and conditions.

The aim of this study is to analyze the relationship between periodontal diseases/conditions and diabetes mellitus, as indicated by this new classification, in addition to promoting a literature review on the subject.

An integrative literature review was carried out, using Medline electronic databases via Pubmed, Scientific Electronic Library Online (Scielo), Scientific and Technical Literature of Latin America and the Caribbean (LILACS) and Virtual Health Library (VHL) between January and February 2019. The terms "Type 2 Diabetes Mellitus," "Periodontal Diseases," and "Periodontitis" were searched, combining Boolean AND/OR operators. Controlled clinical studies, literature reviews and consensus available in English, Portuguese or Spanish were considered as inclusion criteria.

\section{DISCUSSION}

DP and DM2 have a close relationship. This correlation has been studied for more than six decades, once it was perceived that periodontal tissues of diabetic patients are less resistant to local irritants; it was unknown at that time that high reactivity of periodontal tissues to these irritants attributes to this fact [13].

Technological evolution has opened the way for the development of methods that have broadened knowledge 
and established new hypotheses about this relationship. Longitudinal studies $[9,10]$ positively associated DM2 with increased risk for development of periodontitis, revealing that the presence of this condition advances disease progression, leading to greater tooth loss. Systematic meta-analysis reviews $[14,15]$ confirm diabetes as an important risk factor and modifier for the development of periodontitis, increasing its chances of incidence or progression by $86 \%$ [1.86; $95 \% \mathrm{Cl} ; 1.3-2.8]$.

The coexistence of diabetes mellitus is considered an important modifying factor in the course of gingivitis and periodontitis, according to the new classification of PD [3]. It should be included as a descriptor in a clinical diagnosis of periodontitis, since this disease in diabetic patients does not have unique phenotypic characteristics, which could characterize it as a distinct condition [16]. Therefore, in this context, periodontitis is considered to be a periodontal manifestation of DM2 [17]. Most of the evidence of the effects of diabetes on periodontal tissues comes from patients with $\mathrm{DM} 2$, because of its prevalence [18].

DM2, in turn, is related to the accumulation of white adipose tissue that promotes the release of hormonal and inflammatory signals [1]. These can contribute to tissue destruction, characteristic of periodontitis. In sick sites of subjects with uncontrolled diabetes and periodontitis, there is a significant increase in levels of IL-6, TNF-a, known pro-inflammatory cytokines able to synergistically stimulate connective tissue degradation, and bone resorption via MMP- 1, which has its production increased by fibroblasts in conditions of hyperglycemia $[19,20]$. Healthy sites of diabetic individuals have higher concentrations of proinflammatory biomarkers than healthy sites of non-diabetic subjects with the same biomarkers [19].

Hyperglycemia is accompanied by excessive production of final glycation residues (AGEs), which can activate the Nuclear Factor-Activator Receptor-Kappa B (NFkB). NFkB is involved in the differentiation of osteoclasts, which act in bone resorption, inducing insulin resistance by promoting the expression of numerous genes related to the production of inflammatory cytokines (IL $1 \beta$, IL6, TNFa) [21]. Hyperglycemia can impair tissue repair mechanisms, leading to increased loss of periodontal insertion, and increased severity of the inflammatory process $[18,22,23]$.
In a study on the influence of glycemic control on periodontal pathogens in patients with DM2, Miranda et al. [24] found an increase in the detection of F. nucleatum in sites with probing depth greater than or equal to $5 \mathrm{~mm}$, in individuals with poor glycemic control. In those with critical control, they observed an increase in the frequency of $\mathrm{T}$. forsythia and four other species belonging to the orange complex. According to other studies $[8,25]$, poor glycemic control in subjects with DM2 is associated with a more pathogenic subgingival microbial profile, which can contribute to the worsening of periodontitis observed in these individuals. There is no evidence, so far, to support a causal relationship between periodontal microbiomes and the presence of diabetes [18].

On the other hand, studies suggest [26] that periodontitis increases the risk for elevated glycemic index in diabetic and non-diabetic individuals, which demonstrates that individuals with periodontitis exhibit a greater chance of developing pre-diabetes and diabetes. The coexistence of periodontitis has also been associated with an increased risk for diabetes complications $[4,18]$, such as retinopathy, nephropathy, diabetic foot, cardiovascular diseases and mortality.

According to available evidence, periodontal therapy can result in a reduction of around $0.40 \%(\mathrm{Cl} 0.27$ 0.65) of glycated hemoglobin ( $\mathrm{Hb1AC}$ ) after 3 months $[11,22]$. However, there is insufficient data to demonstrate that this result is maintained for 6 months. The combined use of antibiotics did not influence the reduction of $\mathrm{Hb} 1 \mathrm{AC}$, beyond that which was provided only by tooth scaling and root planing among patients with DM2 [18].

The new classification of PD included tools for individual assessment of patients, recognizing risk factors that may interfere negatively in treatment response. The occurrence of metabolic lack of control in periodontal patients with DM2 is considered an important factor for evaluation in disease progression rate [17], which, as seen, tends to be more accelerated in uncontrolled diabetic individuals.

Algorithm is a tool that systematizes the patient's individual clinical data, with the purpose of grouping them into categories which indicate the severity/complexity and rate of disease progression through well-defined criteria (chart 1) $[3,17]$. 
Chart 1. Structure summarized for the stage and degree of periodontitis.

\begin{tabular}{|l|l|l|l|l|}
\hline & \multicolumn{3}{|c|}{ Severity of IIIness and Complexity of Treatment } \\
\hline \multirow{2}{*}{$\begin{array}{l}\text { Individual Stage and Degree } \\
\text { Assessment }\end{array}$} & $\begin{array}{c}\text { Stage I } \\
\text { Initial Peridontitis }\end{array}$ & $\begin{array}{c}\text { Stage II } \\
\text { Moderate Peridontitis }\end{array}$ & $\begin{array}{c}\text { Stage III } \\
\text { Severe Peridontitis with } \\
\text { potential of additional } \\
\text { dental deterioration }\end{array}$ & $\begin{array}{c}\text { Advances Peridontitis with } \\
\text { extensive dental deterioration } \\
\text { and potential for tooth loss }\end{array}$ \\
\hline $\begin{array}{l}\text { Evidence or risk of rapid } \\
\text { progression, early response } \\
\text { to treatment, and systemic } \\
\text { health effects }\end{array}$ & Grade A & Slow progression. Without risk modification factors \\
\cline { 2 - 4 } & Grade C & Rapid progression. Risk modification factors: smoking (>10 cigarettes/day; HbA1C $\geq 7 \%)$. \\
\hline
\end{tabular}

Source: Adapted by Tonetti et al. [17].

The new classification system defines a kind of staging of periodontitis at various points in time, aiming to facilitate communication between professionals and assist in the definition of the prognosis for improving personalized care. It is understood that individuals have different severity/extension, rates of disease progression and/or associated risk factors [3,17].

According to the new classification [17], the information derived from this staging should be complemented by data about the biological level of the disease (risk or current evidence of progression) for each patient. The purpose of this gradation is to consider the patient's susceptibility to periodontitis, taking into account his clinical history, manifested by the bone loss/year ratio, and risk determinants that acted together to cause bone loss throughout his life [27].

The occurrence of recognized modifying risk factors, such as smoking and diabetes mellitus, has the power to increase the degree value, regardless of the primary criterion, represented by the rate of progression. For example, a stage II case, characterized by moderate loss of insertion, would assume a moderate rate of progression (Grade B). The detection of DM2, with poor metabolic control, could change the classification of the grade to $C$ [17].

The 1999 Classification [28] already considered diabetes as an important modifying factor for periodontitis, capable of altering its course and expression. Periodontitis in diabetic patients was considered a manifestation of systemic disease. Under the new classification system [3], diabetes is grouped as a systemic disease that affects periodontal support tissues. Diabetes is believed to promote a hyperinflammatory response to bacterial challenge, driven by the interaction between advanced glycation end products (AGE) and their receptors (RAGE), which have increased circulation and expression in diabetic individuals [29].

\section{CONCLUSION}

The metabolic lack of control in diabetics, under the new classification, gains a more prominent position, since it is considered as an individual classification tool of the disease, in its staging and gradation. The diagnostic description will be periodontitis associated with diabetes mellitus, defining the stage and evaluating the degree of the disease, by its rate of progression over time. The degree, however, can be modified by the patient's metabolic control factors.

\section{Collaborators}

OLIVEIRA LML, bibliographical survey, article preparation, review process and writting of the final article. BARBOSA LM, bibliographical survey and review process.

\section{REFERENCES}

1. Santos RA, Lyra RUY, Cavalcanti NEY. Diabetes Mellitus e Doenças Cardiovasculares. 1ed. Rio de Janeiro: Forense; 2014.p. 496.

2. Association American Diabetes. Diagnosis and classification of diabetes mellitus. Diabetes Care. 2014;37(S1):S81-S90. https://dx.doi.org/10.2337/dc10-S062

3. Caton JG, Armitage G, Berglundh T, Chaple ILC, Jepsen S, Kornman KS et al. A new classification scheme for periodontal and peri-implant diseases and conditions - Introduction and key changesfrom the 1999 classification. J Periodontol. 
2018;89(Suppl1): S1-S8. https://dx.doi.org/10.1002/JPER.180157

4. Peter S, Izakovicova HL. Bidirectional association between diabetes mellitus and inflammatory periodontal disease. A review. Biomedical Papers. 2014;158(1):35-38. https://dx.doi. org/10.5507/bp.2014.005

5. Frencken JE, Sharma P, Stenhouse L, Green D, Laverty D, Dietrich T. Global epidemiology of dental caries and severe periodontitis-a comprehensive review. J Clin Periodontol. 2017;44(S18): S94-S105. https://dx.doi.org/10.1111/jcpe.12677

6. Federação Internacional do Diabetes. IDF Diabetes Atlas [Internet]. 8th ed. Brussels: International Diabetes Federation. 2017 [cited 2019 Jan 19]. Available from: <http://www.idf. org/diabetesatlas>

7. Costa AF, Flor LS, Campos MR, Oliveira AF, Costa MFS, Silva RS, et al. Carga do diabetes mellitus tipo 2 no Brasil. Cad Saúde Pública. 2017;33(2):e00197915. https://dx.doi. org/10.1590/0102-311X00197915

8. Llambés F, Arias-Herrera S, Caffesse R. Relationship between diabetes and periodontal infection. World J Diabetes. 2015; 6(7):927-935. https://dx.doi.org/10.4239/wjd.v6.i7.927

9. Demmer RT, Papapanou PN. Epidemiologic patterns of chronic and aggressive periodontitis. Periodontology 2000. 2010; 53 (1):28-44. https://dx.doi.org/10.1111/j.1600-0757.2009.00326.x

10. Jimenez M, Hu FB, Marino M, Li Y, Joshipura KJ. Type 2 diabetes mellitus and 20 year incidence of periodontitis and tooth loss. Diabetes Res Clin Pract. 2012;98(3):494-500. https://dx.doi.org/10.1016/j.diabres.2012.09.039

11. Madianos PN, Koromanttzos PA. An update of the evidence on the potential impact of periodontal therapy on diabetes outcomes. J Clin Periodontol. 2018;45:188-195. https://dx. doi.org/10.1111/jcpe.12836

12. Myllymäk V, Saxlin T, Knuuttila $M$, Rajala $U$, KeinänenKiukaanniemi S, Anttila $S$, et al. Association between periodontal condition and the development of type 2 diabetes mellitus-Results from a 15-year follow-up study. J Clin Periodontol. 2018;45:1276-1286. https://dx.doi.org10. 1111/jcpe. 13005

13. Ray HG, Orban B. The gingival structures in diabetes mellitus. J Periodontol. 1950;21(2):85-95. https://dx.doi.org/10.1902/ jop.1950.21.2.85

14. Chávarry NGM, Vettore MV, Sansome C, Sheiham A. The relationship between diabetes mellitus and destructive periodontal disease: a meta-analysis. Oral Health Prev Dent. 2009;7(2):107-27.

15. Nascimento GG, Leite FRM, Vestergaard P, Scheutz F, López R. Does diabetes increase the risk of periodontitis? A systematic review and meta-regression analysis of longitudinal prospective studies. Acta Diabetol. 2018;55(7):653-667. https://dx.doi.org/10.1007/s00592-018-1120-4

16. Jepsen S, Caton JG, Albanar JM, Bissada NF, Bouchard $P$, Cortellini $\mathrm{P}$, et al. Periodontal manifestations of systemic diseases and developmental and acquired conditions: consensus report of workgroup 3 of the 2017 World Workshop on the Classification of Periodontal and PeriImplant Diseases and Conditions. J Periodont. 2018;45(Suppl 20):S219-S229. https://dx.doi.org/10.1111/jcpe.12951

17. Tonetti MS, Greenwel H, Kornman KS. Staging and grading of periodontitis: Framework and proposal of a new classification and case definition. 2018;89(Suppl 1):S159-S172. https://dx. doi.org/10.1002/JPER.18-0006

18. Sanz M, Ceriello A, Buysschaert M, Chapple I, Demmer RT, Graziani $F$, et al. Scientific evidence on the links between periodontal diseases and diabetes: Consensus report and guidelines of the joint workshop on periodontal diseases and diabetes by the International Diabetes Federation and the European Federation of Periodontology. J Clin Periodontol. 2018;45:138-149. https://dx.doi.org/10.1111/jcpe.12808

19. Duarte PM, Bezerra JP, Miranda TS, Feres M, Chambrone L, Shaddox LM. Local levels of inflammatory mediators in uncontrolled type 2 diabetic subjects with chronic periodontitis. J Clin Periodontol. 2014;41(1):11-18. https:// dx.doi.org/10.1111/jcpe.12179

20. Lew JH, Naruishi K, Kajiura Y, Nishikawa Y, Ikuta T, Kido J, et al. High glucose-mediated cytokine regulation in gingival fibroblasts and thp-1 macrophage: a possible mechanism of severe periodontitis with diabetes. Cell Physiol Biochem. 2018;50:973-986. https://dx.doi.org/10.1159/000494481

21. Shoelson SE, Lee J, Goldfine AB. Inflammation and insulin resistance. J Clinical Invest. 2006;116 (7):1793-1801. https:// dx.doi.org/10.1172/JCI29069

22. Chee B, Park B, Bartold PM. Periodontitis and type II diabetes: a two-way relationship. Int J Evid Based Healthc. 2013;11(4):317-329. https://dx.doi.org/10.1111/1744-1609. 12038

23. Bahki D, Kaur G, Singh D, Sahota J, Thakur A, Grover S. Estimation of plasma levels of tumor necrosis factor-a, interleukin-4 and 6 in patients with chronic periodontitis and type II diabetes mellitus. J Contemp Dent Pract. 2018;19(2):166-169. https://dx.doi.org/10.5005/jp-journals10024-2231

24. Miranda TS, Feres M, Retamal-Valdés B, Perez-Chaparro PJ, Maciel SS, Duarte PM. Influence of glycemic control on the levels of subgingival periodontal pathogens in patients with generalized chronic periodontitis and type 2 diabetes. J Appl Oral Sci. 2017;25(1):82-89. http://dx.doi.org/10.1590/167877572016-0302

25. Babev EA, Balmasova IP, Mkrtumyan AM, Kostryukova SN, Vakhitova ES, Il'ina EM, et al. Metagenomic analysis of gingival sulcus microbiota and pathogenesis of periodontitis associated with type 2 diabetes mellitus. 2017;163(3):682686. http://dx.doi.org/10.1007/s10517-017-3888-6

26. Graziani F, Gennail S, Soline A, Petrini M. A systematic review and meta-analysis of epidemiologic observational evidence on the effect of periodontitis on diabetes. J Clin Periodontol. 2018;45:167-187. http://dx.doi.org/doi.org/10.1111/jcpe. 12 837 
27. Dietrich T, Ower P, Tank M, West NX, Walter C, Needleman I, et al. Periodontal diagnosis in the context of the 2017 classification system of periodontal diseases and conditions implementation in clinical practice. Br Dent J. 2019;226(1):16-22. http://dx.doi.org/10.1038/s41415-019-0042-z

28. Armitage GC. Development of a classification system for periodontal diseases and conditions. Ann Periodontol. 1999;4(1):1-6. http://dx.doi.org/10.1902/annals.1999.4.1.1
29. Albanar JM, Susin C, Hughes FJ. Manifestations of systemic diseases and conditions that affect the periodontal attachment apparatus: Case definitions and diagnostic considerations. J Periodontol. 2017; 89(Suppl 1): S183-S203. http://dx.doi. org/10.1111/jcpe. 12947

Received on: 19/4/2019

Final version resubmitted on: 30/12/2019

Approved on: 3/3/2020 